\title{
RELATIONSHIP BETWEEN FORE-UDDER ATTACHMENT AND TEAT LENGTH IN HOLSTEIN FRIESIAN COWS AS AFFECTED BY MILKING SPEED
}

\author{
A.A. Amin \\ Department of Animal Production, Faculty of Agriculture, University of Suez \\ Canal, 41522- Ismailia, Egypt
}

\section{SUMMARY}

Fore-udder attachment (FUA) and teat length (TL) have been introduced as the most important udder conformation traits for developing general udder health. Milking speed is an important functional traits controlling either the relationship between both traits and/ or the rate of mastitis infection. The objective of the current study was therefore to evaluate the relationship between FUA and TL and the impact of milking speed on this relationship using random regression model. Results of the present work were obtained by using a random regression model with a third-order Legendre polynomial for both additive genetic and permanent environmental effects. Data consisted of 94721 sample test-day records of the first two parities obtained from the Hungarian Holstein-Friesian population. Stage of lactation was divided into seven unequal days-in-milk group. Milking speed was classified into fast, medium and slow milking rates. Average estimates of heritability for FUA and TL were $0.36 \pm 0.05$ and $0.26 \pm 0.04$, respectively. Average estimates of additive genetic and permanent environmental correlations of $F U A^{*} T L$ were $-0.32 \pm 0.03$ and $0.13 \pm 0.09$, respectively. Large additive genetic variation and highest estimates of heritability for TL and FUA were obtained within the medium milking speed group ranging from 0.26 to 0.42 and from 0.15 to 0.44 for both traits, respectively. These results would be considered favorable because medium milking speed did not cause increase in milk somatic cell (good milk quality), keep udder tissue in a good texture and optimize labor costs during milking process. As evident from the current results, selection for short teats will be associated with tighter fore-udder attachment. Achieving such breeding goal would reduce rates of mastitis infection and increase total net profit of dairy farm.

Keywords: milking speed, teat length, fore-udder attachment

\section{INTRODUCTION}

In most countries, dairy cattle breeding programs are mainly oriented towards milk production traits with some consideration towards conformation traits. Although these traits are of primary economic importance, functional traits, such as udder health and milkability traits are of increased interest to minimize rates of mastitis infection. Batra and McAllister (1984) and Seykora et al. (1985) have examined relationships between some udder conformation traits with different measures of milking speed and reported somewhat variable results, but genetic correlations

Issued by The Egyptian Society of Animal Production 
between most of udder traits and milking speed tended to be favorable. Udder health index showed high results in mastitis resistance by including udder traits as evidence of increasing genetic correlations between udder traits with somatic cell score and clinical mastitis and milking speed. On the other hand, increasing milking speed is associated with decreased milking labor time which is a significant expense in the harvest of milk. Unfortunately, increased milking speed may also be associated with increased incidence of clinical mastitis. Increased milking speed can be the result of decreased tension of the teat sphincter, and a relatively weak sphincter provides less resistance to infection of the udder by pathogens.. Udder type traits, and teat structure, have been identified as traits that are potentially useful for indirect selection to improve udder health and increasing mastitis resistance. To utilize these traits properly in breeding programs, detailed information is needed about their interrelationships. In addition, genetic relationships are needed to facilitate international genetic evaluations (Rogers, 1993, Seykora and McDaniel, 1986, and Shook 1989). Several approaches have been proposed, ranging from a simple repeatability model to a full multivariate model for evaluating udder conformation traits. Most of current studies try to use random regression models for explaining additive genetic and permanent environmental variations across the time trajectory for several economic dairy traits.

The objective of the present work was to study the relationship among some udder traits within different milking speed groups using random regression procedure.

\section{MATERIALS AND METHODS}

Data consisted of 94721 test-day observations on fore-udder attachment (FUA) and teat length (TL). Test-day observation wee taken on 3864 cows daughters of 3012 dams and 361 sires Milking speed ( $\mathrm{kg} /$ minute) was recorded for each animal at the same day of recording udder form. The current data set involved the first two parities of Hungarian Holstein Friesian cows which provided from Hungarian Holstein Association. Milking speed was classified into three groups as i) fast milking ( $\geq 4 \mathrm{~kg} / \mathrm{min})$, ii) slow milking $(<1.7 \mathrm{~kg} / \mathrm{min})$ and iii) medium milking was in between the previous two groups with average $2.6 \mathrm{~kg} / \mathrm{min}$. All studied traits were required to be recorded on each test-day during both lactations. Cows had to have at least five measurements in the first lactation, while the average was 8.3 test-day records. All animals have a complete pedigree (sire and dam). Data were extracted from cows calving between 1998 and 2002. Stage of lactation was divided into 7 groups of days in milk (DIM) with unequal intervals. Structure of the current data set is given in Table 1.

\section{Mathematical Model}

The following random regression animal model was used:

$$
Y_{i j k p}=A_{i}+H T D_{j}+D I M_{k}+\sum_{n=0}^{r} \beta_{p n} Z_{k n}+\sum_{n=0}^{t} \alpha_{p n} Z_{k n}+\varepsilon_{i j k p}
$$

Where :- $Y_{i j k p}$ is the test-day observation, $A_{i}$ is the fixed effect of age at calving; $\mathrm{HTD}_{\mathrm{j}}$ is the fixed effect of herd-test-day; DIM $\mathrm{k}$ is the fixed effect of days in milk; 
$Z_{\mathrm{kn}}$ is the polynomial $\mathbf{n}$ for $\mathrm{DIM}_{\mathrm{k}}$, where $\mathbf{n}=(0, \ldots, \mathrm{r})$ for permanent environmental effects and $\mathbf{n}=(0, \ldots ., \mathrm{t})$ for additive genetic effects; $\beta_{\mathrm{pn}}$ is the random regression coefficient on $Z_{\mathrm{kn}}$ for the permanent environmental effect of cow $\mathrm{p} ; \alpha_{\mathrm{pn}}$ is the random regression coefficients on $\mathrm{Z}_{\mathrm{kn}}$, for the additive genetic effect of animal $\mathrm{p}$ and $\varepsilon_{\text {ijkp }}$ is the random residual variance.

Additive genetic $\sigma^{2} a_{k}$ and permanent environmental $\sigma^{2} c_{k}$ variances and heritabilities at DIM $k$ were calculated as:

$$
\sigma^{2} a_{k}=z_{k}^{\prime} G z_{k}, \quad \sigma^{2} c_{k}=z_{k}^{\prime} P z_{k}, \quad h_{k}^{2}=\frac{\sigma^{2} a_{k}}{\sigma^{2} a_{k}+\sigma^{2} c_{k}+\sigma_{e}^{2}}
$$

where : $Z_{k}$ is the vector of polynomials in the model for $D_{\mathrm{k}}, \mathrm{G}$ : is the (co)variance matrix for additive genetic random regression coefficients, $P$ is the (co)variance matrix for permanent environmental random regression coefficients and $\sigma^{2} e$ is the random residual variance.

Table 1. Description of traits and elementary statistics and distribution of testday record across days in milk groups (DIM) within the first two parities and milking speed groups.

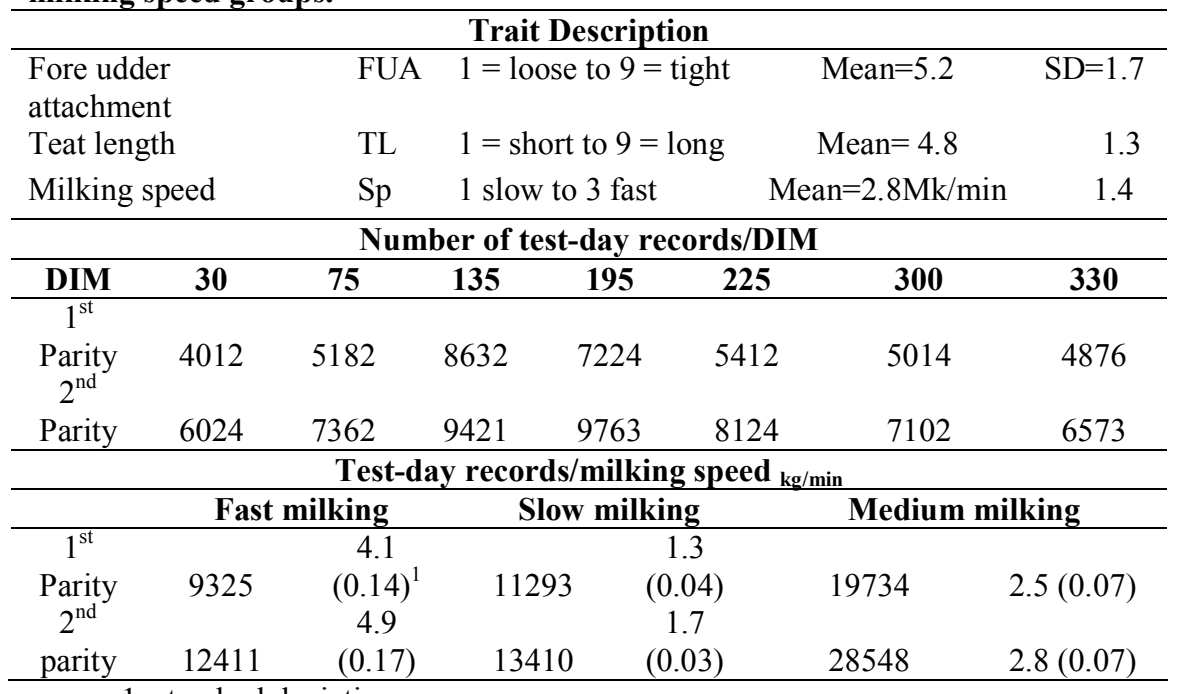

1: standard deviation

Software package of DFREML (Meyer, 1998 Version 3ß) was used for fitting random regression model.

\section{RESULTS AND DISCUSSION}

\section{Estimates of heritability}

Estimates of heritability for fore-udder attachment and teat length are provided in Table 2. Estimates of heritability for teat length $\left(\mathrm{h}^{2}{ }_{\mathrm{TL}}\right)$ were low to intermediate and 
ranged from 0.079 to 0.441 which progressed with advancing DIM. On the other hand, the corresponding contribution of permanent environmental effect was high and represented not less than $50 \%$ across lactation. The lowest values were obtained during the last thirty days in milk. Variation among estimates of $\mathrm{h}^{2} \mathrm{TL}$ was higher than for $\mathrm{C}_{\mathrm{TL}}^{2}$. Estimates of heritability for TL within the first two parities ranged from 0.12 to 0.39 and from 0.19 to 0.51 , respectively and increased markedly_towards the end of trajectory. These results may indicate that, higher improvement could be attained if selection for teat length could be practiced during the late lactation.

Table 2. Estimates of heritability $\left(h^{2}\right)$, permanent environmental effect $\left(C^{2}\right)$, additive $\left(\sigma^{2} a\right)$ and permanent environmental $\left(\sigma^{2} c\right)$ variances for teat length (TL) and fore udder attachment (FUA)

\begin{tabular}{|c|c|c|c|c|c|c|c|c|c|c|c|c|}
\hline \multirow{3}{*}{$\begin{array}{c}\text { DIM } \\
\mathbf{3 0}\end{array}$} & \multicolumn{4}{|c|}{ TL } & \multirow{2}{*}{\multicolumn{2}{|c|}{$\begin{array}{c}\text { Parity }^{1,2} \\
\mathrm{~h}^{2}\end{array}$}} & \multicolumn{4}{|c|}{ FUA } & \multirow{2}{*}{\multicolumn{2}{|c|}{$\begin{array}{c}\text { Parity }^{1,2} \\
h^{2} \\
\end{array}$}} \\
\hline & $\sigma_{a}^{2}$ & $\sigma_{c}^{2}$ & $\mathbf{h}^{2}$ & $\mathrm{C}^{2}$ & & & $\sigma_{a}^{2}$ & $\sigma_{c}^{2}$ & $\mathbf{h}^{2}$ & $\mathbf{C}^{2}$ & & \\
\hline & 0.15 & 1.31 & 0.08 & 0.68 & 0.12 & 0.19 & 19.1 & 28.97 & 0.23 & 0.35 & 0.18 & 0.41 \\
\hline 75 & 0.55 & 1.97 & 0.18 & 0.66 & 0.19 & 0.19 & 28.5 & 8.51 & 0.40 & 0.12 & 0.33 & 0.41 \\
\hline 135 & 0.93 & 2.58 & 0.24 & 0.65 & 0.22 & 0.21 & 38.2 & 4.07 & 0.50 & 0.05 & 0.42 & 0.54 \\
\hline 195 & 1.14 & 3.12 & 0.24 & 0.66 & 0.24 & 0.32 & 37.6 & 5.33 & 0.49 & 0.07 & 0.42 & 0.51 \\
\hline 225 & 1.43 & 3.17 & 0.28 & 0.63 & 0.29 & 0.44 & 26.3 & 3.01 & 0.41 & 0.05 & 0.23 & 0.37 \\
\hline 300 & 1.72 & 2.57 & 0.36 & 0.54 & 0.37 & 0.45 & 14.9 & 1.11 & 0.30 & 0.02 & 0.22 & 0.29 \\
\hline 330 & 2.04 & 2.13 & 0.44 & 0.46 & 0.39 & 0.51 & 9.2 & 3.26 & 0.20 & 0.07 & 0.21 & 0.27 \\
\hline
\end{tabular}

Estimates of heritability for fore-udder attachment $\left(\mathrm{h}_{\mathrm{FUA}}^{2}\right)$ were higher than for TL across lactation and ranged from 0.196 to 0.499 . The highest inheritance effects on FUA were obtained from $\mathrm{DIM}^{135}$ to DIM ${ }^{195}$. Estimates of $\mathrm{h}^{2}$ FUA within the first two parities ranged from 0.18 to 0.42 and from 0.270 .54 , respectively. It reflects the development influences of gene action on performance of FUA with progressing lactation order. Permanent environmental effects had low contribution to variations in measurements of FUA (from 0.02 to 0.07 except the $1^{\text {st }}$ two DIM). Therefore, reduced $h_{\text {FUA }}^{2}$ values during the late of lactation may be attributed to lower additive genetic variance.

Boettcher et al. (1998) found that estimates of heritability for udder traits were all within the range of 0.06 to 0.20 and were slightly greater than the heritabilities mostly applied for the Canadian genetic evaluation of conformation traits (Jamrozik et al., 1991). While the latter author reported that, teat traits were the udder traits with the highest heritabilities. Hiemstra et al. (2000) found that, heritability estimates for fore-udder attachment and teat length were 0.41 and 0.48 , respectively. Teat length was more heritable $\left(\mathrm{h}^{2}=0.30\right)$ than fore-udder attachment $\left(\mathrm{h}^{2}=0.18\right)$ as reported by Rupp and Boichard (1999). DeGroot et al. (2002) found that teat length and foreudder attachment were long and strong in direction with heritability estimates and residual variances being $0.29 \pm 0.09$ for both with similar residual variances. 


\section{Correlations between measurements within each trait across lactation}

Estimates of additive genetic and permanent environmental correlations either within FUA or within TL are illustrated in Figure 1. Teat length during the first $\mathrm{DIM}^{30}$ showed highest additive correlations with the other measures across lactation (ranged from 0.42 to 0.92 with a mean of $0.73+0.09$ ). On the other hand, TL within $\mathrm{DIM}^{75}$ showed the widest range and the lowest correlations with the other measures during the remaining part of lactation (ranging from 0.03 to 0.97 with a mean of $0.49 \pm 0.17)$. Correlations of the $1^{\text {st }}$ and the $2^{\text {nd }}$ measure of FUA with the others ranged from 0.25 to 0.95 (mean $=0.67 \pm 0.11$ ) and 0.47 to 0.98 (mean $=0.79 \pm 0.09$ ), respectively. Additive genetic correlations within fore udder attachment were mostly higher than within teat length. Also correlations decreased as lactation proceeds especially within teat length. It appears that, early measurements are not the best indicator for early prediction. Therefore, teat length could be considered as different trait especially around both edges of trajectory. On the other hand, permanent environmental correlations within teat length were positive, very high and increased with progressing lactation. Permanent environmental correlations between measurements of fore udder attachment were low and changed to negative with increasing distance between measures.
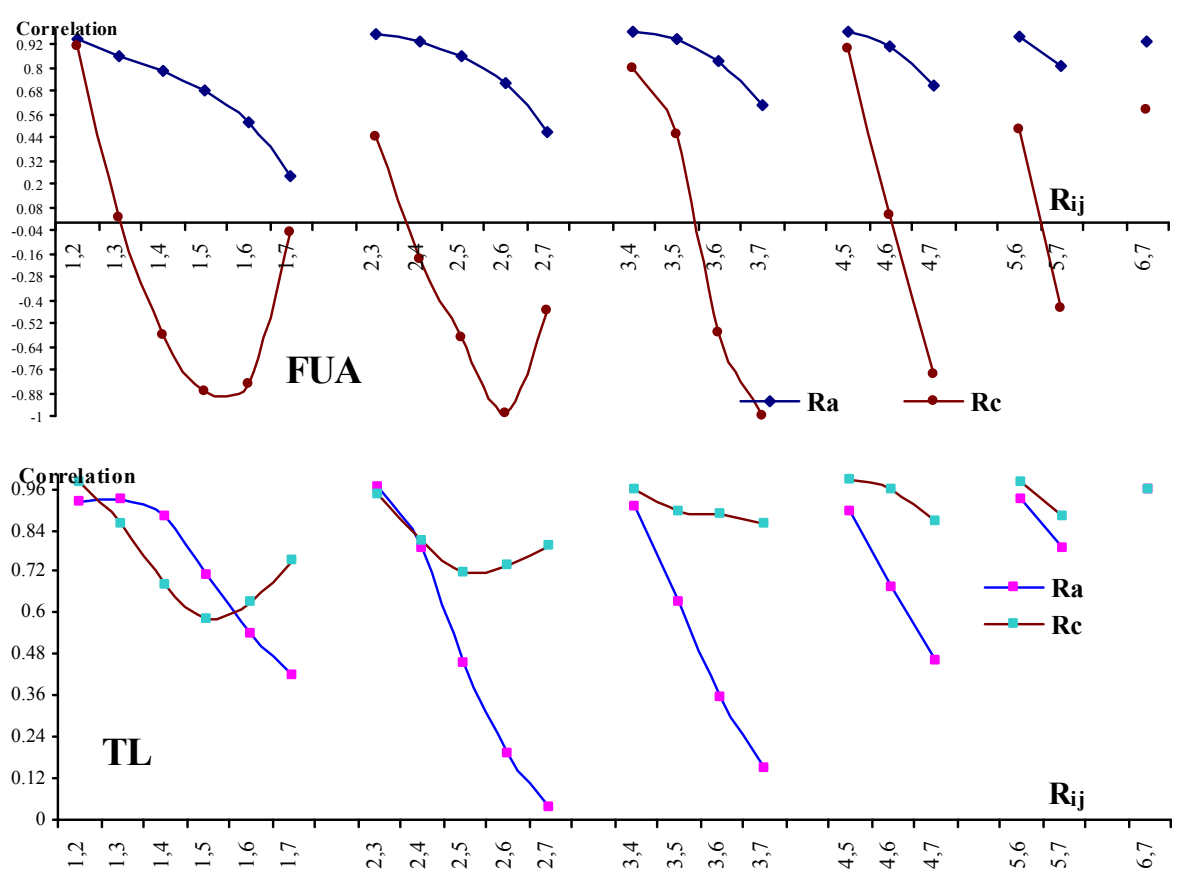

Fig. 1. Additive and permanent environmental correlations within both of fore udder attachment (FUA) and teat length (TL) across days in milk groups 


\section{Correlations between teat length and fore-udder attachment}

Estimates of additive ( $\left(\mathrm{Ra}_{\mathrm{TL} * \mathrm{FUA}}\right)$ and permanent environmental $\left(\mathrm{Rc}_{\mathrm{TL}{ }^{*} \mathrm{FUA}}\right)$ correlations are illustrated in Figure 2. Estimates for $\mathrm{Rc}_{\mathrm{TL} * \mathrm{FUA}}$ and $\mathrm{Ra}_{\mathrm{TL}}{ }_{\mathrm{FUA}}$ ranged from 0.03 to 0.22 and from -0.23 to -0.46 with means of $0.13 \pm 0.09$ and $-0.32 \pm 0.03$, respectively. The highest correlation estimates were obtained during $\mathrm{DIM}^{225}$, while the lowest were found at both ends of the trajectory. It appears that environmental conditions had low contributions than additive genetic effect in controlling the relationship between teat length and fore udder attachment. Negative additive genetic covariance between both traits may indicate the possibility for improving both based on variations during the $2^{\text {nd }}$ half of lactation. Achieving such breeding goal will be beneficial in reducing mastitis rates and improving general udder health. Rupp and Boichard (1999) reported that genetic correlations of fore-udder attachment with most of udder health traits ranged from -0.46 to -0.32 . DeGroot et al. (2002) found that udder and teat traits were genetically positively correlated with each other except for teat length. Teat length had negative genetic correlations with other udder traits reaching -0.23 with fore-udder attachment, indicating that shorter teats were associated with tighter attachments and closer teats.

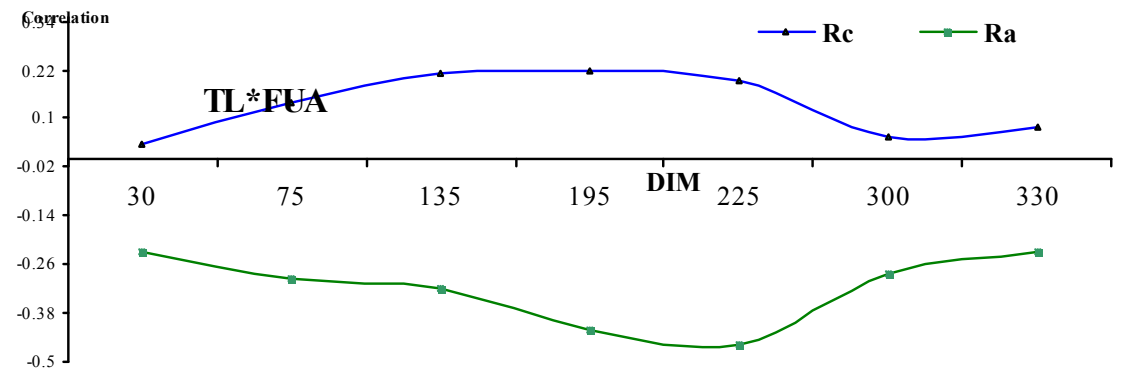

Fig. 2. Estimates of additive (Ra) and permanent environmental correlations (Rc) among teat length (TL) and fore-udder attachment (FUA) across days in milk groups

\section{Relationships between milking speed with each of fore-udder attachment and teat length}

Correlation estimates between milking speed (Sp) with each of fore udder attachment and teat length are illustrated in Figure 3. Estimates of additive genetic correlation $\mathrm{Ra}_{\mathrm{TL} * \mathrm{Sp}}$ were negative and showed polynomial curve shape where values ranged from -0.20 to -0.66 (mean $=-0.40 \pm 0.06$ ). The highest correlations were obtained at $\operatorname{DIM}^{30}(-0.66)$ and at $\operatorname{DIM}^{195}(-0.56)$. These results imply that cows with short teat could eject their milk faster during early and mid-lactation. It appears that selection against long teats will reduce milking cost but may increase nonenvironmentally mastitis infection as an evidence of positive additive correlations between mastitis and milking speed (Rogers et al., 1991). On the other hand short teats within medium milking speed could be preventing high lactating cows from mastitis infection. Accordingly some effort should be done to avoid the increasing possibility of mastitis infection while selecting for Sp. Boettcher et al. (1998) 
reported negative association (-0.38) between milking speed and teat length, they concluded that some cows with longer teats are milked considerably slower. Monardes et al. (1990) and Rogers et al. (1991) concluded that large teats and fast milking speed are strongly associated with increased mastitis. These characteristics are important because they increase the chance of injury and exposure to pathogens from the cow's environment. In cows with long teats, report showed strong association between teat length and both of milk somatic cell and mastitis incidence (De Jong and Landsbergen, 1996 and Seykora and McDaniel, 1986). These authors observed high clinical mastitis incidence for cows with long teats. While Rogaers et al. (1998) found that udder traits were strongly positively correlated with fore-udder attachment but showed low negative association with teat length.

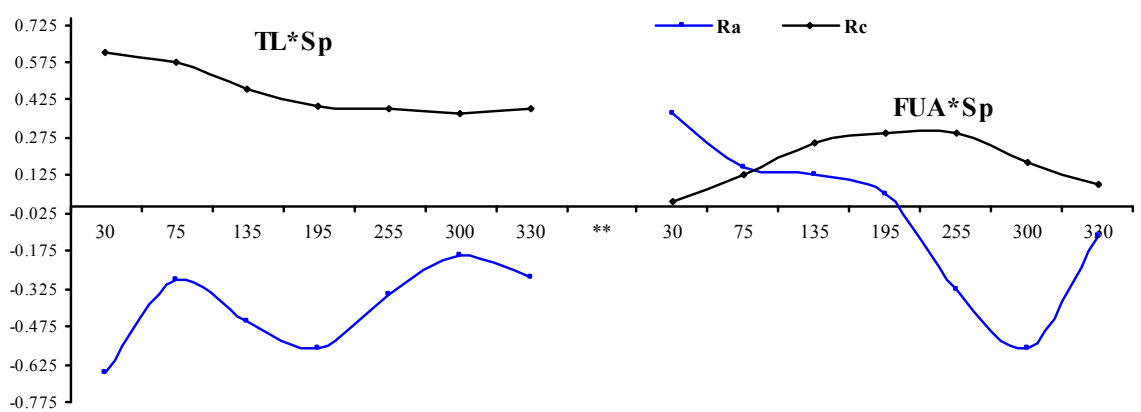

Fig. 3. Estimates of additive (Ra) and permanent environmental (Rc) correlations between teat length (TL) and fore udder attachment (FUA) with milking speed (Sp) across days in milk groups

Estimates of additive genetic relationship $\mathrm{Ra}_{\mathrm{FUA}} \mathrm{Sp}_{\mathrm{Sp}}$ (Figure 3 ) were positive across the first $\operatorname{DIM}^{225}(0.05$ to 0.37 , mean $=0.18+.07)$ but negative and increased in magnitude towards lactation end $(-0.11$ to $-0.5 \overline{6}$, mean $=-0.33 \pm 0.13)$. It appears that, increasing milking speed tend to make fore-udder attachment looser towards lactation end. Such result is mostly unfavorable because looser fore-udder attachment tends to reduce milk production and increases the probability of mastitis infection. This result is supported by Hiemstra et al. (2000) and Rogers et al. (1991), who found strong negative correlation between milking speed and clinical mastitis which means that slow milking cows suffer more from clinical mastitis. The current results were in agreement with Boettcher et al. (1998) who found that, among udder conformation traits, udder attachment showed the greatest genetic correlation with milking speed (absolute value) being -0.24 , indicating that tighter fore-udder attachment was genetically associated with slower milking speed.

Permanent environmental effects had a pronounced role in controlling the relationship between $\mathrm{Sp}$ with each of teat length and fore udder attachment. The current results showed that environmental conditions had greater effect on $\mathrm{TL}^{*} \mathrm{Sp}$ (0.37 to 0.61 , mean $=0.46 \pm 0.04)$ than on $\mathrm{FUA}^{*} \mathrm{Sp}(0.02$ to 0.29 , mean $=0.18 \pm 0.04)$. Estimates of Rc for TL*Sp decreased moderately with progressing lactation while the corresponding estimates for FUA*Sp dropped greatly after DIM $^{195}$ and before $\mathrm{DIM}^{300}$. This means that FUA was less sensitive to changing environmental 
conditions than TL. From another point of view, shape or form of teat length could be the best predictor to reflect all unsuitable mechanical conditions during milking process.

Heritabilities and permanent environmental effects for both udder traits within levels of milking speed

Estimates of heritability and permanent environmental effect for FUA and TL within the three levels of milking speed are shown in Table 3. Estimates of $\mathrm{h}^{2} \mathrm{TL}$ ranged from 0.11 to 0.24 ( $\bar{X}: 0.19), 0.11$ to $0.32(\bar{X}: 0.24)$ and 0.23 to $0.42(\bar{X}$ : 0.32 ), across lactation within fast, slow and medium milking speed group, respectively. It appears that, inheritance impact on TL was lower either with fast or slow milking cows than within medium milking group. Estimates of $h^{2}{ }_{T L}$ decreased with progressing DIM within fast and slow milking group. The maximum hereditary effect on measurements of teat length was obtained during mid lactation within medium milking group. The highest influence of environmental factors on teat length occurred within the fast milking group. These results indicate that, milking speed had a great effect on variation in teat length either due to environmental and /or genetic effects. Selection for improving form of teat length could be better done within medium milking speed. The current estimates were lower than those reported by Seykora, and McDaniel. (1985) ranging from 0.31 to 0.63 based on a single observation in a sire model for teat length.

Table 3. Estimates of heritability and permanent environmental effect for TL and FUA within different three milking speed across DIM groups

\begin{tabular}{cccccccccccccc}
\hline \multirow{2}{*}{ DIM } & \multicolumn{3}{c}{ Fast Milking } & \multicolumn{4}{c}{ Slow Milking } & \multicolumn{3}{c}{ Medium Milking } \\
\cline { 2 - 14 } & \multicolumn{2}{c}{ TL } & \multicolumn{2}{c}{ FUA } & \multicolumn{2}{c}{ TL } & \multicolumn{2}{c}{ FUA } & \multicolumn{2}{c}{ TL } & \multicolumn{2}{c}{ FUA } \\
\cline { 2 - 14 } & $\mathbf{h}^{\mathbf{2}}$ & $\mathbf{C}^{\mathbf{2}}$ & $\mathbf{h}^{\mathbf{2}}$ & $\mathbf{C}^{\mathbf{2}}$ & $\mathbf{h}^{\mathbf{2}}$ & $\mathbf{C}^{\mathbf{2}}$ & $\mathbf{h}^{\mathbf{2}}$ & $\mathbf{C}^{\mathbf{2}}$ & $\mathbf{h}^{\mathbf{2}}$ & $\mathbf{C}^{\mathbf{2}}$ & $\mathbf{h}^{\mathbf{2}}$ & $\mathbf{C}^{\mathbf{2}}$ \\
$\mathbf{3 0}$ & 0.24 & 0.34 & 0.18 & 0.07 & 0.32 & 0.59 & 0.16 & 0.22 & 0.26 & 0.58 & 0.15 & 0.41 \\
$\mathbf{7 5}$ & 0.22 & 0.34 & 0.19 & 0.02 & 0.32 & 0.58 & 0.19 & 0.09 & 0.29 & 0.52 & 0.33 & 0.17 \\
$\mathbf{1 3 5}$ & 0.22 & 0.33 & 0.18 & 0.0 & 0.28 & 0.57 & 0.21 & 0.01 & 0.42 & 0.53 & 0.44 & 0.09 \\
$\mathbf{1 9 5}$ & 0.18 & 0.33 & 0.16 & 0.02 & 0.24 & 0.57 & 0.21 & 0.01 & 0.40 & 0.55 & 0.43 & 0.09 \\
$\mathbf{2 2 5}$ & 0.15 & 0.33 & 0.15 & 0.04 & 0.19 & 0.58 & 0.20 & 0.02 & 0.35 & 0.51 & 0.37 & 0.05 \\
$\mathbf{3 0 0}$ & 0.13 & 0.38 & 0.12 & 0.09 & 0.17 & 0.59 & 0.19 & 0.04 & 0.31 & 0.46 & 0.26 & 0.03 \\
$\mathbf{3 3 0}$ & 0.11 & 0.42 & 0.11 & 0.10 & 0.17 & 0.60 & 0.19 & 0.04 & 0.23 & 0.46 & 0.17 & 0.12 \\
\hline
\end{tabular}

Standard error for h2 0.01 to 0.04 for C2 from 0.07 to 0.13

Estimates of $\mathrm{h}_{\text {FUA }}^{2}$ ranged from 0.11 to $0.18(\bar{X}=0.16)$, from 0.16 to $0.21(\bar{X}=$ $0.19)$, and from 0.15 to $0.44(\bar{X}=0.33)$, across lactation within fast, slow and medium milking speed group, respectively. Estimates of $h_{\text {FUA }}^{2}$ were higher than the corresponding $\mathrm{h}_{\mathrm{TL}}^{2}$. On the other hand, the role of permanent environmental effect was minimized in controlling the performance of FUA across lactation within all milking speed groups. It seems that better results for both traits could be achieved when selection is based in a medium milking speed group. Improving teat length and fore udder attachment within medium milking speed would lead to lower rates of mastitis infection. 
Vukasinovic et al. (2002) found that teat length had the highest heritability among twenty three conformation traits that ranged from 0.17 to 0.51 , while FUA came in the $3^{\text {rd }}$ order (0.41). Also Weigel et al. (1998) came to a similar conclusion.

\section{Correlations between both udder traits within levels of milking speed}

Correlation estimates between fore-udder attachment and teat length within levels of milking speed are presented in Table 4. Additive genetic relationship between FUA and TL were negative and moderately high, being $-0.628\left(\mathrm{DIM}^{225}\right)$, and markedly high being -0.82 to -0.92 (DIM ${ }^{135-225}$ ) within fast and slow milking speed group, respectively. On the other hand, few positive additive genetic correlations between FUA and TL were observed in the low level across fast and medium milking speed. These results may suggest that, strong FUA generally tended to be transmitted with short teats across generations. Rogers (1997) found that, teat length has high negative genetic correlations with fore-udder attachment and udder depth. It appears that, selection for short teats seems to have been effective for general udder health.

Table 4. Estimates of additive, permanent environmental and phenotypic correlations between FUA and TL within different milking speed groups

\begin{tabular}{cccccccccc}
\hline & \multicolumn{3}{c}{ Fast } & \multicolumn{4}{c}{ Slow } & \multicolumn{3}{c}{ Medium } \\
\cline { 2 - 10 } DIM & $\mathbf{R}_{\mathbf{a}}$ & $\mathbf{R}_{\mathbf{c}}$ & $\mathbf{R}_{\mathbf{p}}$ & $\mathbf{R}_{\mathbf{a}}$ & $\mathbf{R}_{\mathbf{c}}$ & $\mathbf{R}_{\mathbf{p}}$ & $\mathbf{R}_{\mathbf{a}}$ & $\mathbf{R}_{\mathbf{c}}$ & $\mathbf{R}_{\mathbf{p}}$ \\
\hline $\mathbf{3 0}$ & 0.084 & 0.578 & 0.632 & -0.389 & -0.134 & -0.411 & -0.391 & -0.185 & -0.503 \\
$\mathbf{7 5}$ & 0.228 & 0.219 & 0.563 & -0.563 & -0.121 & -0.830 & -0.306 & 0.059 & -0.211 \\
$\mathbf{1 3 5}$ & -0.063 & -0.055 & -0.093 & -0.874 & 0.021 & -0.113 & -0.164 & 0.685 & 0.830 \\
$\mathbf{1 9 5}$ & -0.266 & -0.078 & -0.321 & -0.922 & 0.235 & -0.921 & 0.018 & 0.338 & 0.263 \\
$\mathbf{2 2 5}$ & -0.628 & -0.042 & -0.432 & -0.818 & 0.210 & -0.632 & -0.125 & 0.222 & 0.412 \\
$\mathbf{3 0 0}$ & -0.347 & 0.041 & -0.411 & -0.501 & -0.138 & -0.632 & -0.432 & 0.046 & 0.322 \\
$\mathbf{3 3 0}$ & -0.344 & 0.075 & -0.473 & -0.390 & -0.275 & -0.432 & -0.552 & 0.005 & 0.527 \\
\hline
\end{tabular}

Standard error for Ra 0.0 to .11 , Rc: 0.04 to .17 , Rp: 0.07 to 0.14

Effects of environmental conditions on the relationship between FUA and TL were low and negative within all milking speed groups. While positive effects showed considerably high values within medium milking speed group.

\section{ACKNOWLEDGEMENTS}

Appreciations and gratefulness are expressed to the Hungarian Holstein Association for providing the linear type and milk production traits of their Holstein cows. Gratitude and thanks are also due to Prof. G. Tibor for his helpful suggestions and support.

\section{REFERENCES}

Batra, T. R., and A. J. McAllister, 1984. Relationships among udder measurements, milking speed, milk yield and CMT scores in young dairy cows. Can. J. Anim. Sci. 64:807-815.

Boettcher, P. J.; J.C.M. Dekkers, and B. W. Kolstad, 1998. Development of an Udder Health Index for Sire Selection Based on Somatic Cell Score, Udder Conformation, and Milking Speed J. Dairy Science 81: 1157-1168. 
De Jong, G., and L. Lansbergen, 1996. Udder health index:selection for mastitis resistance. Pages 42-47 in INTERBULL Bull. no. 12. Int. Bull Eval. Serv., Gembloux, Belgium.

DeGroot, B.J., J.F. Keown, L.D. Van Vleck, and E.L. Marotz, 2002. Genetic parameters and responses of linear type, yield traits, and somatic cell scores to divergent selection for predicted transmitting ability for type in Holsteins. J. Dairy Sci. 85:1578-1585

Hiemstra, A, A. B Groen, H. Bovenhuis, B. Ducro, and G. Jong, 2000. Estimation of covariances between mastitis incidence, somatic cell count, udder conformation and milk production in Dutch Holstein Friesian dairy cattle Animal Breeding and Genetics Group, Wageningen Institute of Animal Sciences (WIAS), Wageningen University, Wageningen, The Netherlands. Report at http://137.224.73.223/abgorg/hs/education/av/mschiemstra.pdf

Jamrozik, J., L. R. Schaeffer, E. B. Burnside, and B. P. Sullivan, 1991. Estimates of heritabilities of Canadian Holstein conformation traits by threshold model. Can. J. Anim. Sci. 71: 629-632.

Meyer, K., 1998. " $\mathrm{D}_{\mathrm{X}} \mathrm{M}_{\mathrm{RR}}$ " a program to estimate covariance functions for longitudinal data by restricted maximum likelihood in proceeding $6^{\text {th }}$ WCGA 12 16 Jan. University New England, Armidale, 27: 465-466.

Monardes, H.G., R.I. Cue, and J.P. Hayes, 1990. Correlations between udder conformation traits and somatic cell count in Canadian Holstein cows. J. Dairy Sci. 73:1337-1345.

Rogers, G.W., 1993. Index selection using milk yield, somatic cell score, udder depth, teat placement, and foot angle. J. Dairy Sci. 76:664-670.

Rogers, G.W., 1997. Genetic evaluations for mastitis and relationship between mastitis and udder type. Penn State University, University Park, PA 16802. Report at http://animalscience.ag.utk.edu/dairy.

Rogers, G.W., G.L. Hargrove, T.J. Lawlor, Jr., and J.L. Ebersole, 1991. Correlations among linear type traits and somatic cell counts. J. Dairy Sci. 74:1087-1091.

Rupp, R. and D. Boichard, 1999. Genetic parameters for clinical mastitis, somatic cell score, production, udder type traits, and milking ease in first lactation Holsteins. J Dairy Sci 82:2198-2204.

Seykora, A.J. and B.T. McDaniel, 1985. Heritabilities of teat traits and their relationships with milk yield, somatic cell count, and percentage of two-minute milk. J. Dairy Sci. 68: 2670-2683.

Seykora, A.J. and B.T. McDaniel, 1986. Genetics statistics and relationships of teat and udder traits, somatic cell counts, and milk production. J. Dairy Sci. 69:23952407.

Shook, G. E., 1989. Selection for disease resistance. J. Dairy Sci. 72:1349-1362.

Vukasinovic, N., Y. Schleppi and N. Kunzi, 2002 Using conformation traits to improve reliability of genetic evaluation for herd life based on survival analysis $\mathrm{J}$. of Dairy Sci. 85.

Weigel, K.A., T.J. Lawlor, Jr., P.M. VanRaden and G.R. Wiggans, 1998. Use of linear type and production data to supplement early predicted transmitting abilities for productive life. J. Dairy Sci. 81:2040-2044. 


\section{العلاقة بين الإمتداد الأمامى للضرع وطول الطمات فى أبقار الهولستين فريزيان متأثرة \\ بسرعة الحليب \\ أثرف أمين}

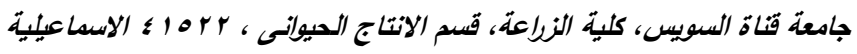

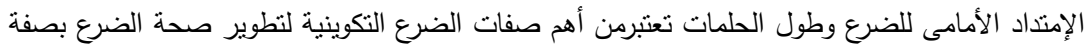

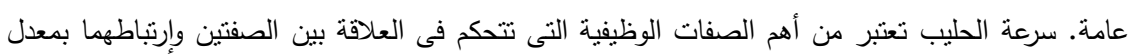

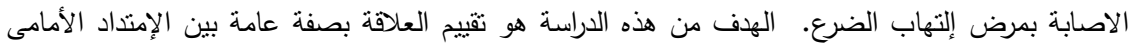

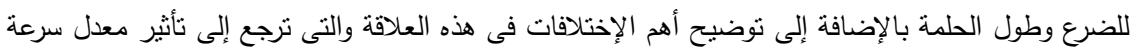

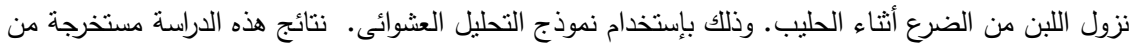

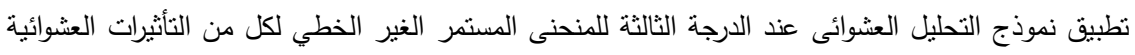

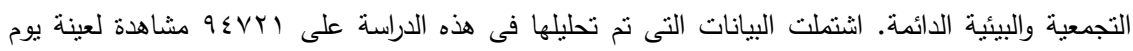

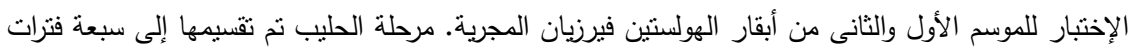

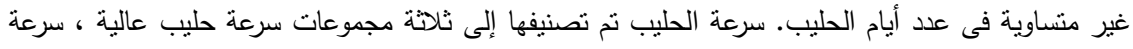

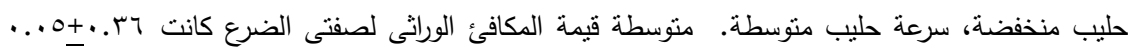

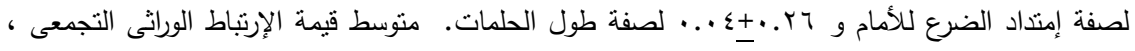

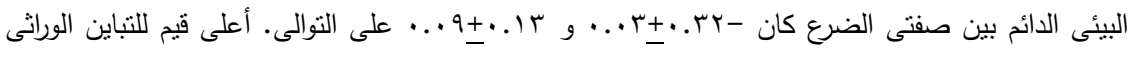

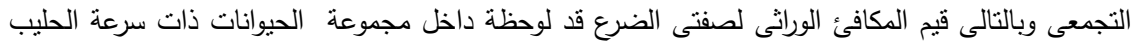

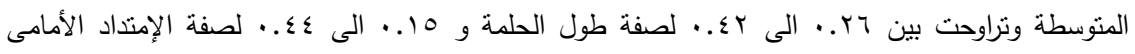

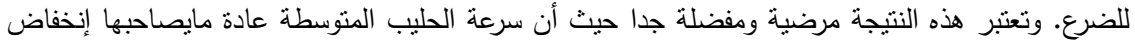

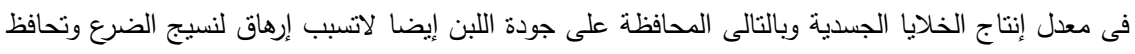
علية فى حالة صحية وظيفية جيدة علاوة على مثالية التكاليف أثناء عملية الحليب داخل المحلب الآلى.

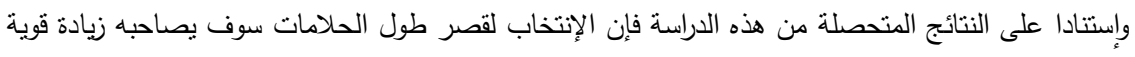

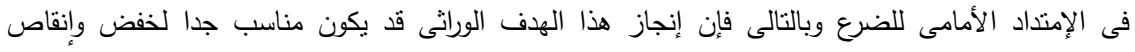
معدلات الإصابة بمرض التهاب الضرع وبالتالى ليالى زيادة العائد الكلى لمزارع الألبان. 